\title{
Vogesella perlucida sp. nov., a non-pigmented bacterium isolated from spring water
}

\author{
Yi-Ju Chou, ${ }^{1}$ Jui-Hsing Chou, ${ }^{2}$ Mei-Chun Lin, ${ }^{1}$ A. B. Arun, ${ }^{2}$ \\ Chiu-Chung Young ${ }^{2}$ and Wen-Ming Chen ${ }^{1}$
}

Correspondence Wen-Ming Chen p62365@ms28.hinet.net

\author{
${ }^{1}$ Laboratory of Microbiology, Department of Seafood Science, National Kaohsiung Marine \\ University, 142 Hai-Chuan Road, Nan-Tzu, Kaohsiung 811, Taiwan \\ ${ }^{2}$ Department of Soil Environmental Science, College of Agriculture and Natural Resources, National \\ Chung Hsing University, Taichung, Taiwan
}

\begin{abstract}
A transparent, non-pigmented, Gram-negative, rod-shaped bacterium, designated strain DS-28 ${ }^{\top}$, was isolated from water samples collected from a spring located in Tainan County, Taiwan. 16S rRNA gene sequence analysis indicated that the novel strain formed a monophyletic branch at the periphery of the evolutionary radiation occupied by the genus Vogesella; the only sole close neighbour of the novel strain was Vogesella indigofera ATCC $19706^{\top}$ (97.4\% 16S rRNA gene sequence similarity). The isolate was distinguished from $V$. indigofera on the basis of genotypic data, several phenotypic properties and an inability to produce characteristic blue-pigmented colonies on peptone agar. The fatty acid profile was slightly different from that reported for $V$. indigofera ATCC $19706^{\top}$. It was evident from the genotypic and phenotypic data that strain DS-28 ${ }^{\top}$ represents a novel species of the genus Vogesella, for which the name Vogesella perlucida sp. nov. is proposed. The type strain is DS-28 ${ }^{\top}\left(=\mathrm{BCRC} 17730^{\top}=\mathrm{LMG} 24214^{\top}\right)$.
\end{abstract}

During the characterization of micro-organisms present in water samples collected from a spring located in Tainan County, Taiwan, several transparent or colourless bacterial colonies were isolated on nutrient agar (BD Difco). All isolates showing similar colony morphology were selected and a representative isolate, designated strain $\mathrm{DS}-28^{\mathrm{T}}$, was selected for detailed analysis. Strain DS $-28^{\mathrm{T}}$ was maintained on R2A agar (BD Difco) plates after incubation at $25{ }^{\circ} \mathrm{C}$ for 3 days. Subculturing was performed on R2A agar at $25{ }^{\circ} \mathrm{C}$ for between 48 and $72 \mathrm{~h}$. On this medium, strain DS- $28^{\mathrm{T}}$ was able to grow at $15-45{ }^{\circ} \mathrm{C}$, but not at 10 or $50{ }^{\circ} \mathrm{C}$.

To ascertain the morphology of strain DS- $28^{\mathrm{T}}$, cells in the lag, exponential and stationary phases of growth were observed under a phase-contrast microscope (DM 2000; Leica). The motility of the cells was tested by means of the hanging drop method. Staining of flagella was performed using the Spot Test Flagella Stain (BD Difco). A Gram stain kit (Set S; BD Difco) and the Ryu non-staining $\mathrm{KOH}$ method (Powers, 1995) were used to test the Gram staining reaction. Poly- $\beta$-hydroxybutyrate granule accumulation was observed under light microscopy after staining the cells with Sudan black. Colony morphology was observed on R2A agar by using a stereoscopic microscope (SMZ 800;

The GenBank/EMBL/DDBJ accession number for the $16 \mathrm{~S}$ rRNA gene sequence of strain DS-28 ${ }^{\top}$ is EF626691.

Colonies, cells and genotypic/phenotypic characteristics of strain DS$28^{\top}$ are compared with those of closely related phylogenetic neighbours in supplementary material available with the online version of this paper.
Nikon). Details of the morphology are given in the species description below.

The $\mathrm{pH}$ range for growth was determined by measuring the optical densities (at $600 \mathrm{~nm}$ ) of cultures grown on nutrient broth (BD Difco) adjusted, prior to sterilization, to various $\mathrm{pH}$ values ( $\mathrm{pH} 4-10$, using increments of $0.5 \mathrm{pH}$ units) using the appropriate biological buffers (Chung et al., 1995). To investigate the tolerance of $\mathrm{NaCl}$, nutrient broth was prepared according to the formula of the BD Difco medium but with $\mathrm{NaCl}$ at various concentrations $(0,0.5$ and $1.0-10.0 \%, \mathrm{w} / \mathrm{v}$, using increments of $1.0 \%)$. Anaerobic growth was determined after incubating strain $\mathrm{DS}-28^{\mathrm{T}}$ in an Oxoid AnaeroGen system. Strain DS- $28^{\mathrm{T}}$ was investigated for a broad range of phenotypic properties. Catalase, oxidase, DNase, urease and lipase activities and hydrolysis of starch, casein, chitin, Tweens 20, 40, 60 and 80 were determined using standard methods (Gerhardt et al. 1994; Lányí, 1987; MacFaddin, 2000). Phenotypic characteristics, biochemical tests, carbon-source utilization (Biolog GN2) and API ZYM, API 20E and API 20NE (all from bioMérieux) reaction profiles were investigated.

The 16S rRNA gene sequence was analysed as described previously by Chen et al. (2001). Analysis of the sequence data was performed by using the BioEdit software package (Hall, 1999) and MEGA version 3.1 (Kumar et al., 2004), after multiple alignment of the data using CLUSTAL_X (Thompson et al., 1997). A distance matrix method (with distance options according to the Kimura two-parameter 


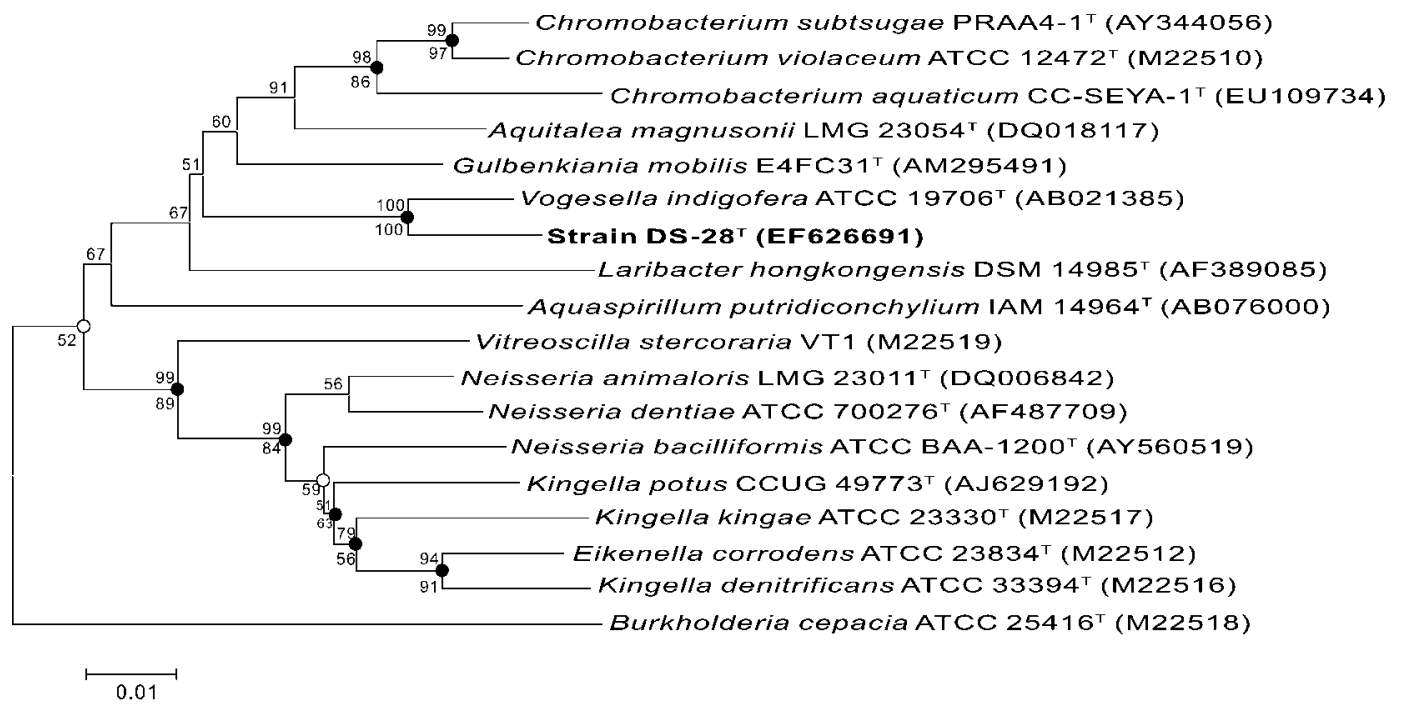

Fig. 1. Phylogenetic tree for strain $D S-28^{\top}$ and related strains, based on $16 S$ rRNA gene sequences available from the EMBL database (accession numbers are given in parentheses), constructed after multiple alignments of data using CLUSTAL_X (Thompson et al., 1997). Distances (with distance options according to the Kimura two-parameter model) and clustering with the neighbour-joining method were performed using the MEGA software package version 3.1 (Kumar et al., 2004). Numbers at the nodes are bootstrap percentages $(>50 \%$ ) based on both neighbour-joining (above nodes) and maximum-parsimony (below nodes) tree-making algorithms. Filled circles indicate branches of the thee that were also recovered using the maximumlikelihood and maximum-parsimony tree-making algorithms. Open circles indicate that the corresponding nodes were also recovered in the tree generated with the maximum-parsimony algorithm. Bar, 0.01 substitutions per nucleotide position.

model; Kimura, 1983), including clustering by neighbourjoining (Saitou \& Nei, 1987) (Fig. 1) and a discrete characterbased maximum-parsimony (Kluge \& Farris, 1969) method, was used. In each case, bootstrap percentages (based on 1000 replications) were calculated. The $16 \mathrm{~S}$ rRNA gene sequence of strain DS- $28^{\mathrm{T}}$ was a continuous stretch of $1414 \mathrm{bp}$. The $16 \mathrm{~S}$ rRNA gene sequence analysis indicated that strain DS- $28^{\mathrm{T}}$ belonged to the class Betaproteobacteria, forming a distinct subline within the genus Vogesella. Bootstrap resampling showed that the association between strain DS- $28^{\mathrm{T}}$ and the type strain of the only recognized member of the genus Vogesella, Vogesella indigofera ATCC $19706^{\mathrm{T}}$, was statistically significant. The 16S rRNA gene sequence similarities (over $1350 \mathrm{bp}$ ) calculated for DS- $28^{\mathrm{T}}$ indicated that the strain was closely related to $V$. indigofera ATCC $19706^{\mathrm{T}}$ (97.4\%), Gulbenkiania mobilis E4FC31 ${ }^{\mathrm{T}}$ (94.6\%), Aquitalea magnusonii TRO-001DR8 ${ }^{\mathrm{T}}$ (93.1\%), Chromobacterium subtsugae PRAA4-1 ${ }^{\mathrm{T}}$ (93.1\%), Chromobacterium violaceum ATCC $12472^{\mathrm{T}}(92.9 \%)$ and Laribacter hongkongensis DSM $14985^{\mathrm{T}}$ $(92.6 \%)$. Lower sequence similarities $(<92.0 \%)$ were found with respect to representative members of the other genera shown in Fig. 1. The overall topologies of the phylogenetic trees obtained using neighbour joining, maximum likelihood or maximum parsimony were similar.

Fatty acid methyl esters were prepared, separated and identified according to the instructions of the Microbial Identification System (Microbial ID; Sasser, 1990). The predominant fatty acid constituents of strain DS- $28^{\mathrm{T}}$ were summed feature $3\left(\mathrm{C}_{16: 1} \omega 7 c\right.$ or iso- $\left.\mathrm{C}_{15: 0} 2-\mathrm{OH}\right)$ and $\mathrm{C}_{16: 0}$. The fatty acid profile of strain DS- $28^{\mathrm{T}}$ was generally comparable with that of $V$. indigofera ATCC $19706^{\mathrm{T}}$, but differed in the proportions of certain fatty acids (Table 1).

The DNA G + C content of strain DS- $28^{\mathrm{T}}$ was estimated $(n=2)$ as described previously by Mesbah et al. (1989). The nucleoside mixture was separated by means of HPLC. The DNA $G+C$ content of strain DS- $28^{\mathrm{T}}$ was found to be $61.8 \pm 1.0 \mathrm{~mol} \%$.

Table 1. Comparison of long-chain fatty acid compositions (\%) of strain DS-28 ${ }^{\top}$ and $V$. indigofera ATCC $19706^{\top}$

Data for $V$. indigofera were taken from the MIDI database. Both strains were grown on tryptic soy broth agar medium at $25{ }^{\circ} \mathrm{C}$.

\begin{tabular}{|c|c|c|}
\hline Fatty acid & Strain DS-28 ${ }^{\mathrm{T}}$ & 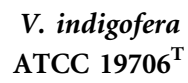 \\
\hline $\mathrm{C}_{10: 0}$ & 2.40 & $-^{*}$ \\
\hline $\mathrm{C}_{10: 0} 3-\mathrm{OH}$ & 4.75 & 5.25 \\
\hline$C_{12: 0}$ & 2.93 & 2.86 \\
\hline $\mathrm{C}_{14: 0}$ & 1.17 & 0.73 \\
\hline$C_{16: 0}$ & 18.10 & 26.62 \\
\hline $\mathrm{C}_{18: 1} \omega 7 c$ & 3.83 & 3.92 \\
\hline Summed feature $3 \dagger$ & 61.68 & 56.88 \\
\hline
\end{tabular}

${ }^{\star}$ Less than $0.5 \%$.

$\dagger$ Summed feature 3 comprises $\mathrm{C}_{16: 1} \omega 7 c$ and/or iso- $\mathrm{C}_{15: 0} 2-\mathrm{OH}$. 
DNA-DNA hybridization experiments were performed with $V$. indigofera ATCC $19706^{\mathrm{T}}$ by using the method described by Ezaki et al. (1989). The results indicated low levels of DNA relatedness between strain DS- $28^{\mathrm{T}}$ and its closest phylogenetic neighbour, $V$. indigofera ATCC $19706^{\mathrm{T}}$ $(7.5 \pm 1.8 \%)$. These values are clearly below the $70 \%$ cutoff point recommended for the assignment of strains to the same genomic species (Wayne et al., 1987).

The sensitivity of strain DS- $28^{\mathrm{T}}$ to different antibiotics was tested after spreading cells $(0.5$ McFarland) on MuellerHinton agar (BD Difco) plates. The antibiotic discs (Oxoid) contained following antibiotics: ampicillin $(10 \mu \mathrm{g})$, chloramphenicol $(30 \mu \mathrm{g})$, gentamicin $(10 \mu \mathrm{g})$, kanamycin $(30 \mu \mathrm{g})$, nalidixic acid $(30 \mu \mathrm{g})$, novobiocin $(30 \mu \mathrm{g})$, rifampicin $(5 \mu \mathrm{g})$, penicillin $\mathrm{G}(10 \mu \mathrm{g})$, streptomycin $(10 \mu \mathrm{g})$, sulfamethoxazole $(23.75 \mu \mathrm{g})$ plus trimethoprim $(1.25 \mu \mathrm{g})$ and tetracycline $(30 \mu \mathrm{g})$. The effects of the antibiotics on cell growth were assessed after 3 days.

Detailed results from the phenotypic and biochemical characterization of strain DS- $28^{\mathrm{T}}$ are provided in Table 2 and in the species description. Phenotypic characteristics that serve to differentiate strain DS- $28^{\mathrm{T}}$ from $V$. indigofera ATCC $19706^{\mathrm{T}}$ and other closely related strains are presented in Table 2 and in Supplementary Table S1 (available in IJSEM Online). Strain DS- $28^{\mathrm{T}}$ was unable to produce the blue-pigmented colonies on peptone agar or R2A agar that are characteristic of $V$. indigofera ATCC $19706^{\mathrm{T}}$ (see Supplementary Fig. S1 in IJSEM Online). Strain DS $-28^{\mathrm{T}}$ produced acid from a few carbohydrates, such as mannitol, inositol and sucrose. Carbon-substrate utilization tests with various sugars and organic acids produced some positive results. In API 20NE tests, strain DS $-28^{\mathrm{T}}$ showed positive reactions for nitrate reduction, indole production and assimilation of glucose, mannitol, $\mathrm{N}$-acetylglucosamine, maltose and malate; negative results were obtained for glucose acidification, arginine dihydrolase, urease, $\beta$-glucosidase, protease, $\beta$-galactosidase and for the assimilation of arabinose, mannose, adipate, phenylacetate, gluconate, caprate and citrate. Strain DS$28^{\mathrm{T}}$ showed positive enzyme reactions (API ZYM) for alkaline phosphatase, esterase (C4), esterase lipase (C8), lipase (C14), leucine arylamidase, valine arylamidase, acid phosphatase, naphthol-AS-BI-phosphohydrolase and $\alpha$ glucosidase, but was negative for cystine arylamidase, trypsin, $\alpha$-chymotrypsin, $\alpha$-galactosidase, $\beta$-galactosidase, $\beta$-glucuronidase, $\beta$-glucosidase, $N$-acetyl- $\beta$-glucosaminidase, $\alpha$-mannosidase and $\alpha$-fucosidase.

On the basis of the data obtained from 16S rRNA gene sequence comparisons, strain DS- $28^{\mathrm{T}}$ occupies a distinct position within the genus Vogesella. This genotypic insight was supported by the unique combination of chemotaxonomic characteristics (Tables 1 and 2) and biochemical traits (Table 2 and Supplementary Table S1) of the novel strain. It is clear from the genotypic and phenotypic data that strain DS $-28^{\mathrm{T}}$ represents a second species of the genus Vogesella, for which the name Vogesella perlucida sp. nov. is proposed.
Table 2. Some genotypic and phenotypic characteristics that can be used to distinguish strain $\mathrm{DS}-28^{\top}$ from its closely related phylogenetic neighbour $V$. indigofera ATCC $19706^{\top}$

Data for the isolation source and the DNA G+C content for $V$. indigofera ATCC $19706^{\mathrm{T}}$ were taken from Grimes et al. (1997); all other data listed were obtained in this study. Both strains were positive for nitrate reduction, indole production, acetoin production, inositol fermentation, oxidase, catalase, alkaline phosphatase, esterase (C4), lipase (C8), leucine arylamidase, valine arylamidase, acid phosphatase, naphthol-AS-BI-phosphohydrolase and for assimilation of $\mathrm{N}$-acetylglucosamine, glucose and malic acid. Both strains were negative for the following: glucose fermentation, gelatin and aesculin hydrolysis, $\mathrm{H}_{2} \mathrm{~S}$ production, urease, $\alpha$-chymotrypsin, cystine arylamidase, $\alpha$-galactosidase, $\beta$-galactosidase, $\beta$-glucuronidase, $\beta$-glucosidase, $N$-acetyl- $\beta$-glucosaminidase, $\alpha$-mannosidase, $\alpha$-fucosidase, lysine decarboxylase, ornithine decarboxylase and for assimilation of arabinose, mannose, capric acid, adipic acid, trisodium citrate and phenylacetic acid.

\begin{tabular}{|c|c|c|}
\hline Characteristic & Strain DS-28 ${ }^{\mathrm{T}}$ & $\begin{array}{l}\text { V. indigofera } \\
\text { ATCC } 19706^{\mathrm{T}}\end{array}$ \\
\hline Isolation source & Spring water & Pond sediment \\
\hline Colony colour & Colourless to white & Blue \\
\hline Lipase (C14) & + & - \\
\hline$\alpha$-Glucosidase & + & - \\
\hline \multicolumn{3}{|l|}{ Fermentation of (API 20E): } \\
\hline Mannitol & + & - \\
\hline Sucrose & + & - \\
\hline Amygdalin & - & + \\
\hline \multicolumn{3}{|l|}{ Assimilation of (API 20NE): } \\
\hline Mannitol & + & - \\
\hline Maltose & + & - \\
\hline Potassium gluconate & - & + \\
\hline \multicolumn{3}{|l|}{ Oxidation of (Biolog): } \\
\hline Sucrose & + & - \\
\hline Inositol & - & + \\
\hline DL-Lactic acid & - & + \\
\hline Propionic acid & - & + \\
\hline Urocanic acid & + & - \\
\hline L-Alanine & - & + \\
\hline L-Asparagine & - & + \\
\hline L-Ornithine & - & + \\
\hline DNA G $+C$ content $(\mathrm{mol} \%)$ & 61.8 & 65.4 \\
\hline
\end{tabular}

\section{Description of Vogesella perlucida sp. nov.}

Vogesella perlucida (per.lu'ci.da. L. fem. adj. perlucida transparent, referring to the transparent and colourless colonies, which distinguish it from the type species $V$. indigofera, which forms blue-pigmented colonies).

Cells are aerobic, Gram-negative, non-spore-forming and rod-shaped. Cells are motile by means of single polar flagellum. Poly- $\beta$-hydroxybutyrate granules are accumulated. After $48 \mathrm{~h}$ growth on $\mathrm{R} 2 \mathrm{~A}$ agar at $25^{\circ} \mathrm{C}$, the mean cell size is approximately $0.5 \times 1.0-2.0 \mu \mathrm{m}$. Visible, round, entire, convex and colourless colonies are formed. The 
colony diameter is approximately $1.0-2.5 \mathrm{~mm}$ on R2A agar after $48 \mathrm{~h}$ incubation at $25^{\circ} \mathrm{C}$. Growth occurs at 4, 10, 15, $25,30,37,42$ and $45{ }^{\circ} \mathrm{C}$, with $0-2 \% \mathrm{NaCl}$ and at $\mathrm{pH} 7-9$. Optimal growth occurs at $30{ }^{\circ} \mathrm{C}, 0.5 \% \mathrm{NaCl}$ and $\mathrm{pH}$ 7.5. Catalase-positive. Positive for cytochrome oxidase, catalase, lipase (corn oil) and hydrolysis of Tweens 20, 40, 60 and 80. Negative for DNase and for hydrolysis of starch, chitin and casein. The major fatty acids are summed feature $3\left(\mathrm{C}_{16: 1} \omega 7 c\right.$ or iso- $\left.\mathrm{C}_{15: 0} \quad 2-\mathrm{OH}\right)$ and $\mathrm{C}_{16: 0}$. Additional phenotypic properties are listed in Table 2. With the Biolog GN2 test system, the following compounds are utilized as sole carbon sources: D-fructose, sucrose, $\mathrm{N}$-acetyl-D-glucosamine, D-psicose, Tweens 40 and 80, hydroxy-L-proline, L-proline, L-glutamic acid, $\beta$ hydroxybutyric acid, $\gamma$-aminobutyric acid and urocanic acid. Unable to oxidize $\alpha$-cyclodextrin, dextrin, glycogen, $\mathrm{N}$-acetyl-D-galactosamine, adonitol, trehalose, turanose, Larabinose, D-arabitol, cellobiose, i-erythritol, L-fucose, Dgalactose, gentiobiose, myo-inositol, $\alpha$-D-lactose, lactulose, D-mannitol, D-mannose, melibiose, methyl $\beta$-D-glucoside, raffinose, L-rhamnose, D-sorbitol, xylitol, pyruvic acid methyl ester, succinic acid monomethyl ester, formic acid, D-gluconic acid, DL-lactic acid, quinic acid, succinic acid, bromosuccinic acid, acetic acid, cis-aconitic acid, citric acid, D-galactonic acid lactone, D-galacturonic acid, Dglucosaminic acid, D-glucuronic acid, $\alpha$-hydroxybutyric acid, $\gamma$-hydroxybutyric acid, $p$-hydroxyphenylacetic acid, itaconic acid, $\alpha$-ketobutyric acid, $\alpha$-ketoglutaric acid, $\alpha$ ketovaleric acid, malonic acid, propionic acid, D-saccharic acid, sebacic acid, succinamic acid, L-alanine, L-asparagine, L-aspartic acid, L-histidine, L-leucine, L-ornithine, DLcarnitine, glucuronamide, L-alaninamide, D-alanine, Lalanyl glycine, glycyl L-aspartic acid, glycyl L-glutamic acid, L-phenylalanine, L-pyroglutamic acid, D-serine, L-serine, Lthreonine, inosine, uridine, thymidine, phenylethylamine, putrescine, 2-aminoethanol, 2,3-butanediol, glycerol, DL- $\alpha$ glycerol-phosphate, $\alpha$-D-glucose 1-phosphate and D-glucose 6-phosphate. Strain DS- $28^{\mathrm{T}}$ is sensitive to tetracycline, kanamycin, rifampicin, gentamicin, penicillin G, chloramphenicol, nalidixic acid, novobiocin, streptomycin, ampicillin and sulfamethoxazole plus trimethoprim.

The type strain, DS- $28^{\mathrm{T}}\left(=\mathrm{BCRC} 17730^{\mathrm{T}}=\mathrm{LMG} 24214^{\mathrm{T}}\right)$, was isolated from a spring in southern Taiwan. The DNA $\mathrm{G}+\mathrm{C}$ content of the type strain $61.8 \mathrm{~mol} \%$.

\section{Acknowledgements}

W. M. C. was supported by grants (NSC 96-2320-B-022-001-MY2 and 96-2313-B-022-001-MY3) from the National Science Council, Taipei, Taiwan, Republic of China.

\section{References}

Chen, W. M., Laevens, S., Lee, T. M., Coenye, T., de Vos, P., Mergeay, M. \& Vandamme, P. (2001). Ralstonia taiwanensis sp. nov., isolated from root nodules of Mimosa species and sputum of a cystic fibrosis patient. Int J Syst Evol Microbiol 51, 1729-1735.
Chung, Y. C., Kobayashi, T., Kanai, H., Akiba, T. \& Kudo, T. (1995). Purification and properties of extracellular amylase from the hyperthermophilic archaeon Thermococccus profundus DT5432. Appl Environ Microbiol 61, 1502-1506.

Ezaki, T., Hashimoto, Y. \& Yabuuchi, E. (1989). Fluorometric deoxyribonucleic acid-deoxyribonucleic acid hybridization in microdilution wells as an alternative to membrane filter hybridization in which radioisotopes are used to determine genetic relatedness among bacterial strains. Int J Syst Bacteriol 39, 224-229.

Gerhardt, P., Murray, R. G. E., Wood, W. A. \& Krieg, N. R. (editors) (1994). Phenotypic characterization. In Methods for General and Molecular Bacteriology, pp. 607-654. Edited by P. Gerhardt. Washington, DC: American Society for Microbiology.

Gillis, M. \& Logan, N. A. (2005). Genus IV. Chromobacterium Bergonzini 1881, $153^{\mathrm{AL}}$. In Bergey's Manual of Systematic Bacteriology, 2nd edn, vol. 2, part C, pp. 824-827. Edited by D. J. Brenner, N. R. Krieg, J. T. Staley \& G. M. Garrity. New York: Springer.

Grimes, D. J., Woese, C. R., MacDonell, M. T. \& Colwell, R. R. (1997). Systematic study of the genus Vogesella gen. nov. and its type species, Vogesella indigofera comb. nov. Int J Syst Bacteriol 47, 19-27.

Hall, T. A. (1999). BioEdit: a user-friendly biological sequence alignment editor and analysis program for Windows 95/98/NT. Nucleic Acids Symp Ser 41, 95-98.

Kimura, M. (1983). The Neutral Theory of Molecular Evolution. Cambridge: Cambridge University Press.

Kluge, A. G. \& Farris, F. S. (1969). Quantitative phyletics and the evolution of anurans. Syst Zool 18, 1-32.

Kumar, S., Tamura, K. \& Nei, M. (2004). MEGA3: integrated software for molecular evolutionary genetics analysis and sequence alignment. Brief Bioinform 5, 150-163.

Lányí, B. (1987). Classical and rapid identification methods for medically important bacteria. Methods Microbiol 19, 1-67.

Lau, H.-T., Faryna, J. \& Triplett, E. W. (2006). Aquitalea magnusonii gen. nov., sp. nov., a novel Gram-negative bacterium isolated from a humic lake. Int J Syst Evol Microbiol 56, 867-871.

MacFaddin, J. F. (2000). Biochemical Tests for the Identification of Medical Bacteria, 3rd edn. Baltimore, MD: Williams \& Wilkins.

Martin, P. A. W., Gundersen-Rindal, D., Blackburn, M. \& Buyer, J. (2007). Chromobacterium subtsugae sp. nov., a betaproteobacterium toxic to Colorado potato beetle and other insect pests. Int J Syst Evol Microbiol 57, 993-999.

Mesbah, M., Premachandran, U. \& Whitman, W. B. (1989). Precise measurement of the $\mathrm{G}+\mathrm{C}$ content of deoxyribonucleic acid by high-performance liquid chromatography. Int J Syst Bacteriol 39, 159-167.

Powers, E. M. (1995). Efficacy of the Ryu nonstaining KOH technique for rapidly determining gram reactions of food-borne and waterborne bacteria and yeasts. Appl Environ Microbiol 61, 3756-3758.

Saitou, N. \& Nei, M. (1987). The neighbor-joining method: a new method for constructing phylogenetic trees. Mol Biol Evol 4, 406-425.

Sasser, M. (1990). Identification of bacteria by gas chromatography of cellular fatty acids, MIDI Technical Note 101. Newark, DE: MIDI Inc.

Thompson, J. D., Gibson, T. J., Plewniak, F., Jeanmougin, F. \& Higgins, D. G. (1997). The CLUSTAL_X windows interface: flexible strategies for multiple sequence alignment aided by quality analysis tools. Nucleic Acids Res 25, 4876-4882.

Vaz-Moreira, I., Nobre, M. F., Nunes, O. C. \& Manaia, C. M. (2007). Gulbenkiania mobilis gen. nov., sp. nov., isolated from treated municipal wastewater. Int J Syst Evol Microbiol 57, 1108-1112. 
Wayne, L. G., Brenner, D. J., Colwell, R. R., Grimont, P. A. D., Kandler, O., Krichevsky, M. I., Moore, L. H., Moore, W. E. C., Murray, R. G. E. \& other authors (1987). International Committee on Systematic
Bacteriology. Report of the ad hoc committee on reconciliation of approaches of bacterial systematics. Int J Syst Bacteriol 37, 463-464. 